ERRATUM OPEN

\title{
Erratum: Random electric field instabilities of relaxor ferroelectrics
}

José R. Arce-Gamboa ${ }^{1}$ and Gian G. Guzmán-Verri ${ }^{1,2}$

npj Quantum Materials (2017)2:55 ; doi:10.1038/s41535-017-0046-3

Erratum to: npj Quantum Materials (2017); doi:10.1038/s41535017-0032-9; Published 13 June 2017

In the original version of this paper, the formula for $\omega_{0}$ used in equation 10 incorrectly contained " $k$ ", which should be " $K$ ". Equation $16 \mathrm{c}$ incorrectly contained the term $3\left(C^{2} / 3\right)$, which should be $C^{2} .3\left(C^{2} / 3\right)$ has also been replaced by $C^{2}$ on page 6 of the PDF in relation to $\mathrm{LO}$ mode frequency.

These corrections have been made to the HTML and PDF versions of this article.

\begin{abstract}
Open Access This article is licensed under a Creative Commons Attribution 4.0 International License, which permits use, sharing, adaptation, distribution and reproduction in any medium or format, as long as you give appropriate credit to the original author(s) and the source, provide a link to the Creative Commons license, and indicate if changes were made. The images or other third party material in this article are included in the article's Creative Commons license, unless indicated otherwise in a credit line to the material. If material is not included in the article's Creative Commons license and your intended use is not permitted by statutory regulation or exceeds the permitted use, you will need to obtain permission directly from the copyright holder. To view a copy of this license, visit http://creativecommons. org/licenses/by/4.0/.
\end{abstract}

(c) The Author(s) 2017

\footnotetext{
${ }^{1}$ Centro de Investigación en Ciencia e Ingeniería de Materiales and Escuela de Física, Universidad de Costa Rica, San José 11501, Costa Rica and ${ }^{2}$ Materials Science Division, Argonne National Laboratory, Argonne 60439 IL, USA

Correspondence: Gian G. Guzmán-Verri (gian.guzman@ucr.ac.cr)
}

Published online: 27 September 2017 